\title{
アスペルギルス・オリゼー群 (III)
}

一麴 菌の 分 類—

\author{
国税庁醸造試験所 $/$ 村 上 英 也
}

\section{III. 諸性質の意義}

\section{形態的性質}

\section{老培養菌草の色}

初めから白色あるいは褐色のままのものは別として一

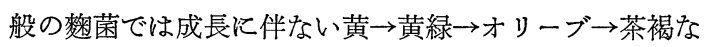
とと変化して不安定であるが, 培湌 1 力月位になると安 定して菌株固有となる。人工によって種々の色の変異株 を得ることが出来るが，坂口勇)によれば焚菌（クロコウ ジカビを含む) の菌草の色, 即ち胞子頭の色は本質的に は白, 黒特よび緑の 3 種に帰せられるという。従って著 者の扱う剓菌では，たとえそれが老培養の色とはいい緑 色を示すか示さないかは基本的に重要であると考兄られ る。またこれは安定した性質であり肉眼によっても容易 に識別出来る性質である。また Fig. 8 に示したように いろいろな性質の中で最も多くの他の性質代対し高度に 相関する性質である（図は 84 株の棅菌について，99\% 有意の相関を示す諸性質の正 (実線), 逆 (波線) の相 関関係を示したもの $)^{27,38,39,40,41)}$ 。また緑色味を保ち, かつ集落裏面の平滑な宷菌はすべてアミラーゼが弱い42)。 若い時から古くなるまで白色の株が最近味噌, 清酒の種

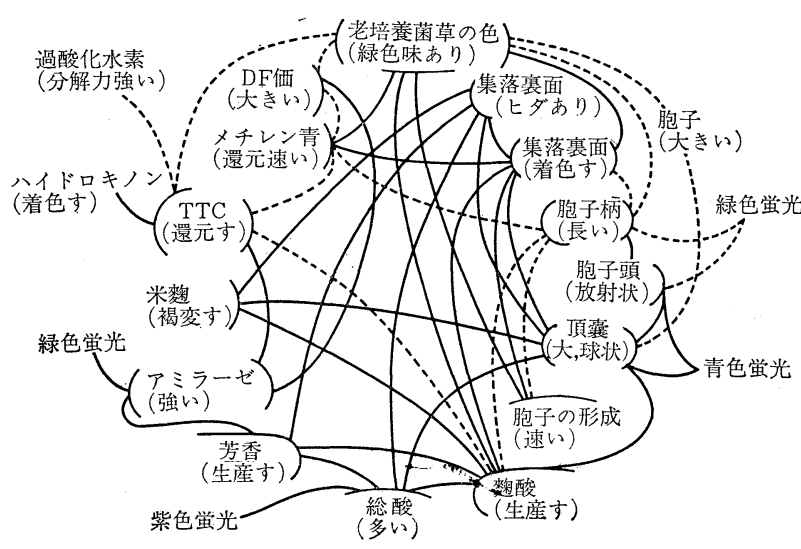

Fig. 8. 主なる性質間の相関関係（84 菌株）
楼から見出されることがありまた麴菌の自然，人工の 変異によって容易に得られるが，菌草が白色といら点 だけで特殊の生理的性質を示すことはない。

\section{色素生産力}

菌種により安定なるのも劣るが，一般的には不安定で あるし ${ }^{43)}$ ，色調に連続性が強いので分類に用いることは むづかしい。然し多産株による醸造物は一般に色が濃い ので菌の利用上は重要である。

\section{硝酸塩難資化性株}

すべての生理活性が弱く, その繁殖も掘く明らかに他 と区別される性質であるが，培養期間を長くすれば他の 株と同様な成長を遂げるので, 分類学的特性とは見なし がたい。

\section{アニスアルデヒド培地における胞子変色}

安定であり, 特汇胞子表面化小突起があり且つ単列梗 子の株は変色するものとしないものとで重要な生理的性 質を異にする。アニス酸培地に拉ける胞子変色は麥菌の 95\%，污染徽 A. flavus の 46\% に見られ，これらを区 別する有力な性質である ${ }^{23,29)}$ 。胞子がピンクに変色する 場合はその培地から常に $p$-methoxyphenol が検出され るが，変色しないものでる検出されることが稀にあり，

この物質はピンク色素生成の前駆体をなすもので あろう。検出されても斜面培養で胞子の変色しな いものは非変色株とする。アニスアルコールーア ニスアルデヒド $\rightarrow$ アス酸 $\rightarrow p$-methoxyphenol $\rightarrow$ pink の代謝経路をすべて完備している株もあ れば一部しかもっていない株もあり，426 株に ついてこれら化合物とピンク変色の関係を菌株の 分布 (\%) にて示すと Fig. 9 の通りである。

一般䴬菌は各種の芳香族化合物を代謝して胞 子や培地が変色し種々の物質を生ずるものもあれ ば，全く代謝しないものもあり，その醭素化学的 違いと分類との間にどのような関係があるか興味 深い問題である ${ }^{44)}$ 。 


\begin{tabular}{|c|c|c|c|c|c|c|c|c|c|}
\hline $\begin{array}{l}\text { p-methoxy } \\
\text { phenol }\end{array}$ & $\dot{0}$ & เே & 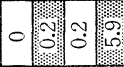 & $\circ{ }^{\circ}$ & 0. & $0 \%$ & i) & $8.9 \%$ & 91.1 \\
\hline Anisic acid & 6.3 & 51.0 & $0.2 \sqrt{6.11}$ & 0 & 1.9 TI & 0.5 & 34.0 & $6.6 \%$ & $93.4 \%$ \\
\hline & & 7.3 & ר? & & 9 & & & $59.7 \%$ & \\
\hline & \multicolumn{3}{|c|}{$63.6 \%$} & \multicolumn{4}{|c|}{$36.4 \%$} & $63.6 \%$ & 6 \\
\hline
\end{tabular}

ピンク変色株

Fig. 9. アニスアルコール，アニスアルデヒド， アニス 酸拉よび $p$-methoxyphenol による胞子変色性の 菌株分布 $(\%)$

Table 9. 顂徽属のアニス酸培地に和ける生育性と胞子の ピンク変色性などによる違い

\begin{tabular}{|c|c|c|c|c|c|c|c|}
\hline \multirow[b]{2}{*}{ 菌 株 名 } & \multirow{2}{*}{ 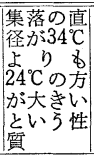 } & \multirow[b]{2}{*}{$\begin{array}{l}\text { 被子 } \\
\text { 器の } \\
\text { 生成 }\end{array}$} & \multirow[b]{2}{*}{$\begin{array}{l}\text { 胞子柄 } \\
\text { 表面の } \\
\text { 粗 状 }\end{array}$} & \multirow[b]{2}{*}{$\begin{array}{l}\text { 麲酸 } \\
\text { の } \\
\text { 生産 }\end{array}$} & \multicolumn{2}{|c|}{ アニス酸の代謝 } & \multirow[b]{2}{*}{$\begin{array}{l}\text { 工業 } \\
\text { 用途 }\end{array}$} \\
\hline & & & & & $\begin{array}{l}\text { アニス酸培 } \\
\text { 地に拘る } \\
\text { 生育の有無 } \\
\text { と胞子変色 } \\
\text { の有無 }\end{array}$ & 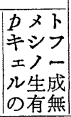 & \\
\hline A. usamii & & - & - & - & - & - & \\
\hline A. usamii var. & & - & - & - & - & - & 焼酎の \\
\hline A. niger & & - & - & - & - & - & 製 造 \\
\hline A. awamori & & - & \pm & - & - & - & \\
\hline A. clavatus & + & - & - & - & 不生育 & - & \\
\hline A. ochraceus & + & - & 冊 & - & 濃ピンク & H & \\
\hline A. fumigatus & & - & - & - & - & - & \\
\hline A. terreus & & - & - & - & ピンク & H & \\
\hline A. glaucus & + & + & 册 & - & 不生 育 & - & \\
\hline A. repens & + & + & 冊 & - & 不生 育 & - & 用 \\
\hline A. ruber & + & + & \pm & - & 不生 巟 & - & \\
\hline A. chevalieri & & + & - & - & 不生育 & - & 途 \\
\hline A. amstelodami & + & + & - & - & 不生 育 & - & ts \\
\hline A. restrictus & + & - & \pm & - & - & - & \\
\hline A. gracilis & + & - & \pm & - & 濃ピンク & H & ᄂ \\
\hline A. variecolor & + & - & - & - & 淡ピンク & - & \\
\hline A. rugulosus & & - & \pm & - & ピンク & 世 & \\
\hline A. ustus & + & - & - & - & - & - & \\
\hline A. flavipes & & - & - & - & 淡ピンク & - & \\
\hline A. versicolor & + & - & - & - & - & - & \\
\hline A. wentii & & - & - & - & ピンク & \# & \\
\hline
\end{tabular}

十, 一の符号はそれぞれ関連する性質の有, 無を示す。

アニスアルデヒドやアニス酸を含む培地では一般に 繁殖が遅くなるが，麥菌はすべて繁殖するのに対し， RAPER-FENNELL の A. flavus group の中 A. zonatus

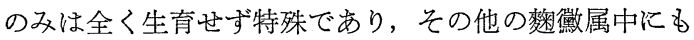
Table 9 の通り生育しないものがあり, これらの培地は その区別に役立つ。

\section{胞子頭の形と大きさ}

小突起胞子やュブ状胞子をもつ株では胞子鎖が互いに 離れてバラバラの放射状を呈し，またある種の株では形 も大ささもほぼ一定している。然し一般的には同一株で
も種々の形や大ささのものを混有し純粋分離をく り返しても単一形を示さないものが少なくない。 推計学的にもこの形や大さと他の諸性質との間に は相関が少ない40)。

\section{胞子柄表面の性質}

広く柇徽属の分類には重要な性質である。麵菌 では一般的に粗であるが，平滑な株も比較的に広 く分布して和り（約 2.5\%)，この性質だけによっ て特殊の菌群とすることはむりかしい(42)。

粗なものは粟粒ようのものが多数付着してお

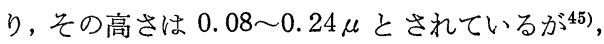
同一株でも粗と平滑を混有して連続性あり，また 人工変異によって平滑から粗に変る傾向がある ${ }^{43)}$ 胞子柄の長さ, 太さは菌種によってかなり固有で あるが高度に連続している。

\section{胞子の大さ（直径）}

菌種により $3 \sim 10 \mu$ 以上にわたる。 $4 \sim 5 \mu$ 以 下の小さいものだけより成る株や 8〜10 $\mu$ 以上の 大きいものだけから成る株では安定している。然 し中位のものは多くの場合大, 中, 小を混有して 連続して和り，人工変異によっても変り易い。而 して変異は小から中 $\rightarrow$ 大の方向へ起り易いので, $4 \sim 5 \mu$ 以下の小さい安定している株は分類学的 に区別するとしても，5～6 はどの大さを以てその株の代表值とするか判定困 難な場合が少なくない。それ故このような場合著 者はこの変異の方向より考えて, なるべく大きく かつ分布の多い胞子の直径を以て代表させること とした。

梗子が復列で小胞子 ( $4 \sim 5 \mu$ 以下) の株はほと んぞすべて稞酸を生産し，また菌核を造るものが 多く, 野生株中にはアフラトキシンを生産するも のがある46)。

\section{胞子表面の性質}

この性質は見易くかつ安定し，人工変異によっ ても変らない43,47)。飯塚 ${ }^{48)}$ はこれにより剓徽属の 胞子を種々に分類したが，麴菌ではその必要はないと思 われる。

小突起 echinulate は 1912 年 A. parasiticus SPEAR について記載され，1944 年坂口がこの性質を重視して 醬油用樬菌のある 1 群を A. sojae と命名したもので 粫菌中 $8 \%$ 見出される ${ }^{42)}$ 。然しこの小突起胞子を諸 外国の研究者は分類学上余り重要視しない。たとえば RAPER-FENNELL の The Genus Aspergillus (1965) では, A. parasiticus の胞子を coarsely echinulate, A. flavus のそれを conspicuously echinulate と記し 
ているに過ぎない。従って著者はたとえこの性質が $A$. parasiticus について先に記載されたとしてもその重要 性を認めていないから, 後にその重要性を認めて命名さ れた坂口・山田の A. sojae は独立の種名を獲得すべき ものと考光る。

小突起胞子株は䴯菌中のもの之野生徽中に見出される ものとでは形態・生理ともに大いに異る。麴菌中のもの は老培養菌草が茶褐色が多く, 胞子柄壁はしぱしば平滑 であり，頂囊小さく $(20 \sim 25 \mu$ 以下) すべ゙て単列梗子で あり,アニスアルデヒド培地で胞子がピンクを呈しな い。これに対し野生徽では, 老培養菌草は概して緑色が 濃く, 胞子柄壁はすべて粗であり, この培地でピンク変 色し，また或る株ではこの培地で变色しないが頂囊大き く梗子が復列であり，ともに多量のアフラトキシンを生 産する。

コブ状 tuberculate は A. tamarii などの褐色䴹菌 に見られ，褐色色素粒が胞子壁に沈積して凹凸を呈する ものである。古くから褐色棅菌の代表株とされてきた A. tamarii KITA WB 429 は梗子が復列であるのに麴 菌中の褐色株は単列であるが，それ以外では形態も生理 もよく似ている。高橋・山本両氏 ${ }^{49}$ の A. oryzae var. fulvus は菌草の状態はやや異なるが, 単列梗子で生理 的には秉菌中の株と区別しにくい。RAPER-FENNELLの A. flavo-furcatis は復列梗子をもち菌草がやや黒味あ る赤褐色を呈し，若いときになんら緑色味を呈しない点 で緑色味を呈する A. tamarii KITA WB 429 と区別さ れているが，これ以外の点では区別されない30)。䴹菌の 中にも若いときに緑色味を呈するものと呈しないものと ありこのような一時的菌草の色の違いは種を決定するほ ど重要ではないと思われる。

\section{頂囊の形と大きさ}

形も大ささも菌種により種々あり，胞子同様にその小 さいもの $(20 \mu$ 以下) は安定しているが，一般には大小 混在して連続して和り, 変異によっても変る ${ }^{43,50)}$ 。

\section{梗子の配列状態}

復列梗子をもつ胞子頭数の全胞子頭数に対する混合率 \%で示す。数 \%以上の株は全榃菌中 $15 \%$ ありその混 合率は一般に $20 \sim 30 \%$ 以下である。低温 $\left(24^{\circ} \mathrm{C}\right)$ で培養 した方が頂囊も大きく復列梗子も多くなる。復列梗子株 はその人工変異株も同様に復列梗子をもって安定であ る。単列梗子株の人工変異株には稀に少数の復列梗子を もつものもあるが不安定で植継保存中にやがて単列に戻 ることが多い43)。この重要な形態的性質は諸外国の研究 者が重視しているものであるが，わが国のそれは殆んど 重視していない。坂口ら51) は種楝を用いないで造った 楝から麴菌を分離し，復列梗子の混合率が 50 ～60\%の
株が多いことを見出してこれらを A. flavus LINK の特 徵としているが, 混合率が数\%でもそれが安定な株は 生理的な特性を示す。即ち䛧徽属は復列梗子をもつこと によって一般にアミラーゼ力が弱くなり，またアフトキ シンを生産したり重要な生理的性質に関連する。

\section{巨大集落}

その状貌は菌の個別認識上有用であるが，その記載が むづかしい。芳香はクリ香, 米橧香, キノコ臭, カビ臭, エステル臭, フハイ臭など種々あり, クリ香, 米棅香を 呈するものは概してアミラーゼ強く, エステル臭, フハ イ臭のものは弱くこれを液体静置培養すると強い果実香 (リンゴ, バナナ) を生ずる。菌核は培朗温度が高いと き $\left(34^{\circ} \mathrm{C}\right)$, 培地は自然培地よりもッァペック培地上で, 斜面よりも集落上で生成し易く, 初め白色で次第に紫 褐, 黒色などに色ずく43)。菌種により数個のものもある が特に野生株では無数生成して集落の全面に分布するる のもある。酸や色素を多産する株に多い52)。生成の理由 が不明であり, 特に椈菌では生産少なくかつ不安定なの で分類の key とすることはむづかしい。集落の直径は

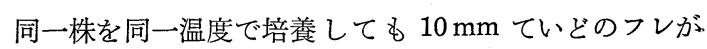
あり, 培地の厚さ即ちペトリ皿内空間の大小に敏感に反 応して不安定である。焼酎・泡盛製造用のクロコウジカ ビも含めてコウジカビ (麥菌) の大多数は $34^{\circ} \mathrm{C}>24^{\circ} \mathrm{C}$ であり，A. glaucus など野生徽のあるものは $34^{\circ} \mathrm{C}<24$ ${ }^{\circ} \mathrm{C}$ でるから, 集落の直径は数值の大小そのものよりも. この両温度に捻いてどちらがより大きいかということの 方が重要な意義をもっている。裏面のヒダは比較的安定 して和り重要な性質に関連し, 老培養菌草が緑色でヒダ のない株はすべてアミラーゼ力が弱い42)。裏面の色は比 較的安定しているが色調が連続しているので, 全く無色 以外の株を相互に分けることはむずかしい。

\section{生理的性質}

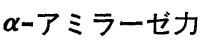

他の諸性質との関係は前記の他に, 復列梗子, 小突起 胞子, 䴹酸非生産の株などは一般に弱く, アフラトキシ ン生産菌も弱くこれらが微生物工業に利用されなかった 理由が肯かれる。然しその弱いものがすべて上記の諸性 質をもつものではなく, 菌のある単一の性質とアミラー ゼ力とを結びつけることはむづかしい。

\section{Mb 還元力}

老培養菌草の色に関連し, 緑味のある株は強く, 緑味 のない株は弱いが, 連続性が強いのでkey としては用い にくい。TTC (Triphenyl tetrazolium chloride) を用 いて $\mathrm{Mb}$ 同様に還元力を測定すると多くの菌株はその強 弱が $\mathrm{Mb}$ と相反するのは興味深い現象である ${ }^{26)} 。$ 


\section{過酸化水素分解力}

菌種により滴定数で $0 \sim 5 \mathrm{~m} l$ の差があるが連続性が強 $\left({ }^{299}\right.$ 。

\section{フェノールの着色性}

ハイドロキノン $(\mathrm{Hq})$ の使用が識別容易であるが， $\mathrm{Hq}$ の着色（赤）はッァペック寒天を用いた場合にのみ 起り，他のどんな自然あるいは人工の培地でる起らな い。これに対しピロガロール（Pg）の着色（茶福）はそ の自動酸化によって対照る多少着色するので見わけにく いが，どんな培地でも起る。これら 2 種のフェノールの 着色は一般に平行し, 常に Pg の方が濃いが, Pgの場合 菌の生育なき対照が着色するのに菌が生育したため全く 着色しない場合があり,これらの着色脱色の機構は複雑 である ${ }^{26)}$ 。実験も識別も容易であるが，やや不安定であ り，また米楸の褐変性，アニスアルデヒドの酸化性， $\mathrm{Mb}$ の還元性などとの間に有意の相関は見られない。

\section{耐酸生産性}

焼酎・泡盛製造用の株を除き, 杽菌の約 $86 \%$ 飞認め られる。培地の種類によっても大いに生産性が異なるの で先ずこれを決定しなければならない。著者はA. oryzae THом No. 113 と A. flavus THOM No. 108 を劃然と

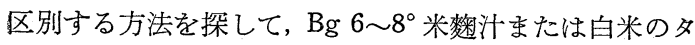
カジアスターゼ消化液 $\left(\mathrm{Bg} 10^{\circ}\right)$ を用いた時に限って前 者が非生産, 後者が生産であるが, これらの培地にペプ トン，醏母エキス，ミネラルその他の物質を添加した り，あるいはこれ以外の培地を用いると区別が出来なく なることを見出した ${ }^{53)}$ 。米麴汁と白米消化液ではほとえ ぞ両結果が一致するが, 後者の方が多少生産に有利であ る。人工変異株を造ると親株にくらべて変異株の方がや や生産するものが多くなる傾向があり，過去 20 年間, 植継ぎ保管して来た株の中約 $4 \%$ が非生産 $\rightarrow$ 生産に変 化した。これらの多くは一時 $\mathrm{FeCl}_{3}$ による紅赤色反応が 微弱なため生産に疑問のある株とされたるのであるか ら, 培養試験を幾回もくり返し, 多少でも生産の傾向を 認めたなら生産株之断定してもよいようである。これに 対し，保管中生産から非生産に転じた株はない299。 THOM No. 113 は K. B. RAPER 教授より 1966 年に分譲 を受けた株であるが年々実験をくり返し 5 年後の現在で 子非生産である。麥酸は一旦生産されてから次第に消費 されるもので每るから，少なくとも 10 日，20日間培養 の 2 点で試験することが必要である。このように麳酸の 生産は完全に安定といらわけにはいかないが，构酸を生

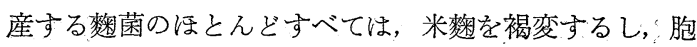
子表面がコブ状の褐色整菌やいわ沛る污染徽 A. flavus のすべてはこれを生産し，また生産株による醇造物は一 般に色が濃く酸化還元電位が高いなど，菌の分類上利用
上無視出来ない性質である。

\section{米麴の褐变}

酸素の存在学必要とし $10^{\circ} \mathrm{C}$ 以下でも速か起り, 醸 造物の着色, 褐变, 酒粕の斑点状褐変（いわゆる黒粕）

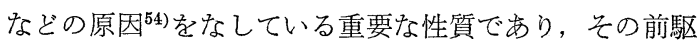
物質は $l$-ドーパ ( $l$-dopa) を主としプロトカテチュウ酸 などより成るものである ${ }^{55,56)}$ 。褐変する株は概してアミ ラーゼ力が強い。また麳菌の多くはよく褐変するが，污 染䰻や野生徽はあまり褐变しない。A. oryzae THOM No. 113 と.A. flavus THOM No. 108 の䴯は, 前者が 褐変し後者は全く褐変しない。親株とその変異株を比較 すると変異株は白米に繁殖し難いものが多くなり，また 褐変するものがやや多くなる傾向があるが43), 褐变性は 概して菌種固有であり，乙ばしば不定に見觉るのはむし ろ培養条件の微少な相違に基づくことが多い。褐变は今 日のところ楝菌が白米（穀類）上に好気的に繁殖する場 合にだけ起り，他のどんな培地にどんな培養法を行なっ ても起らない。米麭浸出液中のドーパを定量することに よって褐変を数值で表わすことが出来るが，菌の分類の key として実験法がやや複雑なので用い難い。この褐 変現象は 1956 年初めて記載されたるのであるがカビに 拈けるとの生理的意義については今後の解明によるとこ ろが多い。米麴の褐変とフェノールの着色性との間に相 関はない。応用的には椈または醸造物に亚硫酸を添加す ることによって褐变が防止される ${ }^{31)} 。$

\section{DF 価}

菌種によって1〜10 倍のひらきがあり，小突起胞子株 は最小で, 污染徽や野生徽にも大きいものはなく,アミ ラーゼ力の強いものは大きい。老培養菌草が緑味を保つ 株は一般に小さい、32)。麴中のデフェリフェリクローム類 の $80 \%$ 以上はデフェリフェリクリシンであって 30〜 $300 \mathrm{ppm}$ 含屯れ, これが鉄と結合して赤色のフェリクリ シンに変化するため醇造物の鉄による着色の原因をな $乙^{57,58)}$ ，また他の成分之共存して醸造物の日光による着 色, 日光臭の発生に関係し ${ }^{59}$, 醇造上極めて重要な成分 である。カビに特けるその生理的意義は呼吸酵素系に鉄 をとり込むための運搬体であると考兄られる。然し分類 の key としては值が連続しているため用い難い。

\section{全生酸力}

䴯菌では通常 0.5 3. $0 \mathrm{~m} l$ で稀に $4 \sim 5 \mathrm{~m} l$ に及ぶも のがあるが，アフラトキシン生産菌には 6 10 $\mathrm{ml}$ 以 上 $^{15,46)}$ ，また焼酎・泡盛用のコウジカビでは $10 \sim 20 \mathrm{ml}$ に及び, 種 species によって相当の差がある。然し值 が連続するので麵菌相互の比較に利用することはむうかか しい。一般济酸を生産するものは酸の生産多く, 菌核 も多酸株に多く見出される。然し静置培養で生酸力を定 
めることは一般に测定值にフレが多 く, 特に人工培養液を用いると值にフ レが多いので, 微少な生酸力の差を以 て菌種を区別することは出来ない。

\section{蛍光性物質}

萃菌の生産する蛍光物質は多く知ら れている。ただ同様の青色蛍光物質で もトリプトフアンとアセトアルデヒド の光化学反応によって生ずるハルマン harman ${ }^{60)}$ は，注とんどすべての生体 産物中に広沉に分布しているもので特 有の微生物の生産物ではない。

近年注目されているのは, 食品中に 痕跡の存在も許されていないアフラト キシンである。日本の麳菌中にこれる 生産するものは皆無であることが各方 面から証明されているが，外国産野生 徽中にはこれを生産するものがあり，貿易によって輸入 食糧に混って侵入する括れもあるので, その菌学的識別 法を確立することが必要である。

\section{白米に生育し難い性質}

このような性質の株は憗菌中約 $3 \%$ 見出されるが，そ れらは汪とんど硝酸塩難資化性, 平滑胞子柄, 小突起胞 子, 復列梗子, 白色胞子, アニスアルデヒド培地で胞子 がピンク非変色などの性質をもつ株に限られて和りいず れもアミラーゼが弱い。生育状態には蒸し米に全く生育 しないものから培養時間を普通の 40 時間よりさらに 10 〜20 時間延長すれば多少生育するものなどあるが明ら かに一般の麴菌に較べれば生育不良である。AHLBURG が初めて麴から分離したカビの特徽として米に良く生育 することを揭げているのは甚だ意義深いことである。米 に対する生育の困難が単に水分, 培養の温度, 湿度, 時 間の違いによるものでないことは明らかであるが，最近 米の化学成分としてフエルラ酸・グルコース・グルタミ ン酸・カルシウムの結合した化合物が見出され6!), この ものが楝菌の生育を甚しく阻害することが知られて括 り，先に記したように米憗汁や白米のタカジアスターゼ 消化液のみが麴酸生産性の点より A. oryzae THOM No. 113 と A. flavus THOM No. 108 を区別することが出 来た事実とともに，米成分の䊝菌の生理に対する影響の 大きいことが推量される。

\section{性質の組合わせ}

菌株の特性は強い影響力をもつ 1 つの性質によって顕
現されるよりも，弱い影響力をもつ性質でもとれが数個 組合って強く顕われることもある。今梗子の配列・アニ ス酸培地の胞子変色性・米䔩汁に和ける猌酸生産性につ いてそれぞれ単復, 変色非変色, 生産非生産に分けて組 合わせると Table 10 のように8 個の組を得る。その結 果いわゆるA. flavus といら名の株はほとんどすべて の組に広く分布するのに対し，これを全く含すず焚菌だ けを含む組は Jであり，6株の㭵菌とA. avenaceus 1 株とより成り, 復列梗子一ピンク変色一棅酸非生産の共 通性質をあつ組である ${ }^{42)}$ 。ただ A. avenaceus は白米に 生育乙難く, 胞子柄壁は平滑であり且つ麴酸を生産しな いが梗子が復列である点に特いて䊝菌とは全く異る。か くてこの組はいわば麴菌の発祥をなす故郷であり，その 中には A. oryzae THOM No. 113 の他に醇造試験所で 50 年以上も前から保管して来ている 1 株 (RIB 430) が ある。

諸性質の組合わせはまた麥菌, 污染徽 A. flavus, 焼 酎・泡盛用のクロコウジカビ, A. clavatus, A. glaucus などの野生徽などの区別に役立つ。即ら菌草の色, 胞子 柄と胞子の表面の性質, 被子器の形成, アニスアルデヒ ドまたはアニス酸を含む培地に和ける生長の難易, 白 米上の生長, 棅酸の生産, 集落直径が $34^{\circ} \mathrm{C}$ 培養と $24^{\circ} \mathrm{C}$ 培養でどちらが大きいかなどの諸性質を組合わせること によってこれらは互いに完全に区別される。 